\title{
HUBUNGAN NILAI HEMATOKRIT DAN NILAI JUMLAH TROMBOSIT PADA PASIEN DEMAM BERDARAH DENGUE
}

\author{
${ }^{1}$ Andrew O. E. Hukom \\ ${ }^{2}$ Sarah M. Warouw \\ ${ }^{3}$ Maya Memah, ${ }^{3}$ Arthur E. Mongan
}

\author{
${ }^{1}$ Kandidat Skripsi Fakultas Kedokteran Universitas Sam Ratulangi Manado \\ ${ }^{2}$ Bagian Ilmu Kesehatan Anak Fakultas Kedokteran Universitas Sam Ratulangi Manado \\ ${ }^{3}$ Bagian Patologi Klinik Fakultas Kedokteran Universitas Sam Ratulangi Manado \\ Email: easterio_hukom@ymail.com
}

\begin{abstract}
Dengue hemorrhagic fever (DHF) has been a global problem especially for children. There are two main pathophysiological changes occur in DHF. The first one is an increased vascular permeability and the second one is the disorder of haemostasis. Haematocrit and thrombocyte count are laboratory parameters that are needed for monitoring the development of DHF. This was a retrospective analytical study with a cross sectional design. Samples were patients who were diagnosed as dengue hemorrhagic fever in RSUP Prof. Dr. R.D. Kandou Manado in 2012. Inclusion criteria were patients aged $<15$ years, were diagnosed based on WHO 1997, and were already tested for haematocrit test and platelet count. Data obtained from the medical records were analyzed by using t test and Spearman's correlation test. There were 137 children with DHF in 2012, and as samples we used 62 children. The t-test of haematocrit values showed a $P$-value 0.0001 which meant that there was a significant increase of haematocrit among DHF patients. The t-test of thrombocyte counts showed a $P$-value 0.0001 , which meant that there was a significant decrease of thrombocyte count among the DHF patients. The Spearman test showed a correlation of haematocrit level and thrombocyte counts among DHF patients with a $P$-value 0.133 . Conclusion: There was no significanct relationship between haematocrit and thrombocyte count among dengue hemorrhagic fever patients.
\end{abstract}

Keywords: dengue hemorrhagic fever, children, haematocrit, thrombocyte coount

\begin{abstract}
Abstrak: Demam berdarah dengue (DBD) telah menjadi masalah masyarakat internasional terutama pada anak-anak. Dua perubahan patologik utama pada penyakit DBD yaitu peningkatan permeabilitas kapiler dan gangguan hemostasis. Hematokrit dan hitung trombosit merupakan parameter laboratorik yang diperlukan untuk memantau perkembangan DBD. Penelitian ini bersifat analitik retrospektif dengan desain potong lintang. Sampel penelitian ialah pasien anak yang terdiagnosis DBD di RSUP Prof. Dr. R. D. Kandou Manado selama periode tahun 2012. Kriteria inklusi ialah pasien berusia $<15$ tahun dan telah terdiagnosis menurut kriteria WHO 1997, serta melakukan pemeriksaan laboratorium hematokrit dan trombosit. Penelitian ini menggunakan catatan rekam medik, dan untuk analisis statistik digunakan uji t dan Spearman's correlation test. Dari 137 anak dengan DBD pada periode 2012, diambil 62 anak sebagai sampel. Melalui uji t untuk hematokrit didapatkan nilai $P=$ 0,0001 yang menunjukkan terdapat peningkatan bermakna nilai hematokrit pada pasien DBD. Melalui uji untuk jumlah trombosit didapatkan nilai $P=0,0001$, yang menunjukkan terdapat penurunan bermakna nilai jumlah trombosit pada pasien DBD. Hasil uji Spearman terhadap korelasi nilai hematokrit dan nilai jumlah trombosit memperlihatkan nilai $P=0,133(\geq \alpha=$ $0,05)$. Simpulan: Tidak terdapat hubungan bermakna antara nilai hematokrit dan nilai jumlah trombosit pada pasien demam berdarah.
\end{abstract}

Kata kunci: demam berdarah dengue,anak, hematokrit, trombosit 
Demam Dengue (DD) dan bentuk beratnya yaitu Demam Berdarah Dengue (DBD) dan Sindrom Syok Dengue (SSD), telah menjadi masalah mendunia. Dalam tiga dekade terakhir, telah terjadi peningkatan frekuensi secara global untuk penyakit DD, DBD, dan SSD. ${ }^{1}$ DBD dapat ditemukan di daerah tropis dan sub-tropis diseluruh dunia, dengan angka kejadian terbanyak di daerah perkotaan. ${ }^{1,2}$

Terdapat dua perubahan patologik utama pada penyakit DBD. ${ }^{3}$ Pertama, terjadi peningkatan permeabilitas kapiler yang dapat menyebabkan kehilangan volue plasma pada pembuluh darah sehingga terjadi hemokonsentrasi. ${ }^{3,4}$ Tanda-tanda lainnya ialah menurunnya tekanan darah dan beberapa tanda dari syok, jika kebocoran plasma semakin parah. ${ }^{3}$ Peningkatan hematokrit sangat banyak ditemukan pada kasus syok sehingga pemeriksaan nilai hematokrit perlu dilakukan dalam pemantauan kasus penyakit DBD. ${ }^{5}$ Kedua, gangguan hemostasis yang disebabkan oleh vaskulopati, trombositopenia, dan juga koagulopati. ${ }^{3}$ Pada DBD, trombositopenia muncul pada hari ke-3 dan tetap bertahan selama perjalanan penyakit tersebut. ${ }^{6}$ Akibat dari gangguan hemostasis ini, maka terjadi manifestasi klinis perdarahan. ${ }^{7}$ Dewi et al. meneliti bahwa nilai jumlah trombosit dapat dipergunakan sebagai faktor untuk memrediksi kejadian syok. ${ }^{8}$

Pada sel darah merah terdapat sebuah unsur yang dapat memengaruhi fungsi trombosit. Unsur tersebut ialah adenosine diphospate (ADP) yang dikenal sebagai salah satu agonis agregasi trombosit. Pelepasan ADP oleh sel darah merah mengakibatkan terjadinya peningkatan agregasi trombosit. $^{9}$ Pada DBD, teori secondary heterologous infection menyatakan bahwa peningkatan agregasi trombosit mengakibatkan penghancuran trombosit oleh reticuloendothelial system (RES) sehingga terjadi trombositopenia. ${ }^{10}$ Dengan meningkatnya nilai hematokrit semakin banyak ADP yang dilepaskan oleh sel darah merah. ${ }^{10}$

Berdasarkan uraian latar belakang diatas, peneliti ingin mengetahui apakah terdapat hubungan antara nilai hematokrit dengan nilai jumlah trombosit pada pasien DBD di RSUP Prof. Dr. R. D. Kandou Manado.

\section{METODE PENELITIAN}

Penelitian ini menggunakan metode retrospektif analitik dengan desain potong lintang. Data yang digunakan merupakan data sekunder dari catatan medik penderita DBD periode tahun 2012. Penelitian dilaksanakan di RSUP Prof. Dr. R.D. Kandou Manado. Pemeriksaan nilai hematokrit dan nilai jumlah trombosit dilakukan di laboratorium RSUP Prof. Dr. R.D. Kandou Manado.

Subjek penelitian ialah pasien yang terdiagnosis DBD menurut kriteria WHO 1997 dengan usia <15 tahun, serta melakukan pemeriksaan laboratorium hematokrit dan trombosit selama periode tahun 2012. Yang termasuk kriteria klinis yaitu demam tinggi mendadak, perdarahan (termasuk uji bendung positif, petekia, epistaksis, dan hematemesis), hepatomegali, syok yang ditandai nadi kecil dan cepat dengan tekanan nadi $<20 \mathrm{mmHg}$, atau hipotensi disertai gelisah dan akral dingin. Yang termasuk kriteria laboratorik ialah trombositopenia $(\leqslant 100.000 / \mathrm{uL})$, hemokonsentrasi (kadar hematokrit $\geq 20 \%$ dari normal). Dua gejala klinis pertama ditambah 2 gejala laboratorik dianggap cukup untuk menegakkan diagnosis kerja DBD.

Data yang terkumpul kemudian dianalisis menggunakan program SPSS 18 for windows. Uji $\mathrm{t}$ digunakan untuk mengetahui apakah terdapat perbedaan antara nilai hematokrit normal dan nilai hematokrit penderita DBD, serta nilai jumlah trombosit normal dan nilai jumlah trombosit penderita DBD. Spearman's correlation test digunakan untuk mengetahui adanya hubungan antara nilai hematokrit dan nilai jumlah trombosit.

\section{HASIL PENELITIAN}

Terdapat 137 anak dengan DBD pada periode 2012, dan 62 anak yang memenuhi kriteria inklusi dan eksklusi menjadi 
sampel penelitian. Sebanyak 22 anak (35,5\%) dengan DBD pada kelompok usia 1-4 tahun, dan 40 anak (64,5\%) pada kelompok usia 5-14 tahun (Tabel 1), serta 29 anak laki-laki (46,8\%) dan 33 anak perempuan (53,2\%) (Tabel 2).

Pada Tabel 3 didapatkan 6 orang anak $(9,7 \%)$ yang memiliki nilai hematokrit dibawah normal, 16 orang anak (25,8\%) yang memiliki nilai hematokrit normal, dan 31 orang anak (50\%) yang memiliki nilai hematokrit diatas normal. Melalui uji t didapatkan nilai $P=0,0001$. Hal ini berarti bahwa terdapat peningkatan bermakna nilai hematokrit pada pasien DBD.

Pada Tabel 4 didapatkan 53 orang anak (85,5\%) dengan trombositopenia, dan 9 orang anak (14,5\%) dengan nilai jumlah trombosit normal. Melalui uji t didapatkan nilai $P=0,0001$. Hal ini berarti bahwa terdapat penurunan bermakna nilai jumlah trombosit pada pasien DBD.
Tabel 1. Distribusi usia penderita DBD

\begin{tabular}{ccc}
\hline Usia Sampel & $\begin{array}{c}\text { Frekuensi } \\
\text { (orang) }\end{array}$ & $\begin{array}{c}\text { Persen } \\
\text { (\%) }\end{array}$ \\
\hline $\begin{array}{c}\text { Kelompok usia } \\
\quad<1 \text { tahun }\end{array}$ & 0 & 0 \\
$\begin{array}{c}\text { Kelompok usia } \\
\text { 1-4 tahun }\end{array}$ & 22 & 35,5 \\
$\begin{array}{c}\text { Kelompok usia } \\
\text { 5-14 tahun } \\
\text { Total }\end{array}$ & 40 & 64,5 \\
\hline
\end{tabular}

Tabel 2. Distribusi jenis kelamin penderita DBD

\begin{tabular}{lll}
\hline Jenis Kelamin & $\begin{array}{l}\text { Frekuensi } \\
\text { (orang) }\end{array}$ & $\begin{array}{l}\text { Persen } \\
\text { (\%) }\end{array}$ \\
\hline Laki - laki & 29 & 46,8 \\
Perempuan & 33 & 53,2 \\
Total & 62 & 100 \\
\hline
\end{tabular}

Tabel 3. Nilai hematokrit

\begin{tabular}{cccccccc}
\hline $\begin{array}{c}\text { Nilai } \\
\text { Hematokrit }\end{array}$ & $\begin{array}{c}\text { Frekuensi } \\
\text { Jumlah }\end{array}$ & $\begin{array}{c}\text { Rata- } \\
\text { rata (\%) }\end{array}$ & $\begin{array}{c}\text { Nilai } \\
\text { Tertinggi } \\
\mathbf{( \% )}\end{array}$ & $\begin{array}{c}\text { Nilai } \\
\text { Terendah } \\
(\%)\end{array}$ & $\begin{array}{c}\text { Simpangan } \\
\text { Baku } \\
(\%)\end{array}$ & P \\
\hline $\begin{array}{c}\text { Hematokrit } \\
\text { rendah } \\
(<35 \%)\end{array}$ & 6 & 9,7 & & & & & \\
$\begin{array}{c}\text { Normal } \\
(35-40 \%)\end{array}$ & 16 & 25,8 & 40,41 & 54,7 & 24,7 & 5,2 & $0,000^{*}$ \\
$\begin{array}{c}\text { Hematokrit } \\
\text { tinggi } \\
(>40 \%)\end{array}$ & 31 & 50 & & & & & \\
\hline
\end{tabular}

Tabel 4. Nilai trombosit

\begin{tabular}{cccccccc}
\hline $\begin{array}{c}\text { Jumlah } \\
\text { Trombosit }\end{array}$ & $\begin{array}{c}\text { Frekuensi } \\
\text { Jumlah }\end{array}$ & $\begin{array}{c}\text { Rata- } \\
\text { rata } \\
\left(/ \mathbf{m m}^{3}\right)\end{array}$ & $\begin{array}{c}\text { Nilai } \\
\text { Tertinggi } \\
\left(/ \mathbf{m m}^{3}\right)\end{array}$ & $\begin{array}{c}\text { Nilai } \\
\text { Terenda } \\
\mathbf{h}\left(\mathbf{m m}^{3}\right)\end{array}$ & $\begin{array}{c}\text { Simpang } \\
\text { an Baku } \\
\left(\mathbf{m m}^{3}\right)\end{array}$ & P \\
\hline $\begin{array}{c}\text { Trombositopenia } \\
\left(<150.000 / \mathrm{mm}^{3}\right)\end{array}$ & 53 & 85,5 & & & & & \\
$\begin{array}{c}\text { Normal } \\
\left(150.000 / \mathrm{mm}^{3}-\right.\end{array}$ & 9 & 14,5 & 84774,1 & 253000 & 6000 & 55692,49 & $0,000^{*}$ \\
$\left.450.000 / \mathrm{mm}^{3}\right)$ & & & 9 & & & & \\
$\begin{array}{c}\text { Trombositosis } \\
\left(>450.000 / \mathrm{mm}^{3}\right)\end{array}$ & 0 & 0 & & & & & \\
\hline
\end{tabular}


Hasil uji Spearman terhadap korelasi nilai hematokrit dan nilai jumlah trombosit menunjukkan nilai $P=0,133(\geq \alpha=0,05)$. Hal ini menunjukkan tidak terdapat hubungan bermakna antara nilai hematokrit dan nilai jumlah trombosit pada pasien DBD di RSUP Prof Dr. R.D. Kandou Manado.

\section{BAHASAN}

Berdasarkan hasil penelitian didapatkan peningkatan bermakna pada nilai hematokrit serta penurunan bermakna pada nilai jumlah trombosit. Hal ini berarti bahwa pemeriksaan hematokrit dan hitung trombosit masih diperlukan pada pasien DBD.

Hasil penelitian melalui uji Spearman memperlihatkan tidak terdapat hubungan bermakna antara nilai hematokrit dan nilai jumlah trombosit pada pasien DBD di RSUP Prof. Dr. R.D. Kandou Manado ( $P>$ 0,05). Hal ini mungkin disebabkan oleh berbagai macam faktor yang memengaruhi baik hematokrit maupun trombosit itu sendiri. Seperti yang telah diketahui, bahwa patogenesis DBD masih dalam tahap penelitian. Para peneliti telah mengajukan berbagai teori mengenai perjalanan penyakit DBD. ${ }^{11,12}$ Teori secondary heterologous dengue infection nampaknya paling menunjang untuk dijadikan dasar penelitian ini, karena menggambarkan tentang peran hematokrit serta trombosit pada DBD, serta menggambarkan hubungan antara keduanya.

Peningkatan agregasi trombosit tidak hanya dipengaruhi oleh peningkatan hematokrit saja. Berbagai faktor dapat memengaruhi terjadinya agregasi trombosit antara lain kompleks virus antibodi maupun trombosit itu sendiri. Dalam trombosit itu sendiri terdapat ADP yang dapat memicu agregasi trombosit. ${ }^{10}$ Noisakran et al. ${ }^{13}$ menemukan bahwa destruksi trombosit tidak hanya disebabkan oleh virus dengue itu sendiri, tetapi juga oleh pertemuan antibodi dengan trombosit yang telah terinfeksi virus dengue.

Peningkatan hematokrit yang bermakna belum tentu menandakan pelepasan ADP dalam jumlah yang cukup untuk dapat memengaruhi nilai jumlah trombosit pada pasien DBD, sehingga tidak mutlak terdapat hasil yang bermakna hubungan antara keduanya.

Kelemahan penelitian ini ialah peneliti menggabungkan DBD tanpa syok dan DBD dengan syok, yang mungkin memengaruhi hasil penelitian yang dilakukan.

\section{SIMPULAN}

Berdasarkan hasil penelitian dapat disim-pulkan bahwa tidak terdapat hubungan bermakna antara nilai hematokrit dan nilai jumlah trombosit pada pasien anak dengan demam berdarah dengue di RSUP Prof. R.D. Kandou Manado.

\section{DAFTAR PUSTAKA}

1. World Health Organization Regional Office for South-East Asia. Comprehensive Guidelines for Prevention and Control of Dengue and Dengue Haemorrhagic Fever [homepage on the Internet]. 2011 [updated 2011 Sep 15; cited 2012 Nov 3]. Available from: http://www.searo.who.int/en/ Section10/Section332/Section554.htm

2. Achmadi UF. Demam berdarah dengue. Buletin Jendela Epidemiologi. 2010;20:1.

3. World Health Organization Geneva. Dengue Haemorrgagic Fever Diagnosis, treatment, prevention and control [homepage on the Internet]. 1997 [cited 2013 Jan 12]. Available from: http://www.who.int/csr/resources/publicati ons/dengue/Denguepublication/en/

4. Nimmamnitya S. Dengue Hemorrhagic Fever Disorders of Hemostasis. International Society of Hematology AsiaPasific Division. 1999:185-6.

5. World Health Organization Regional Office for South-East Asia. Clinical Manifestations and diagnosis [homepage on the Internet]. 2011 [cited 2012 Nov 3]. Available from: http://www.searo.who.int/ en/Section10/Section332/Section554.htm.

6. Srichaikul $T$, Nimmannitya $S$, Sripaisarn T, Kamolsilpa M, Pulgate C. Platelet function during the acute phase of dengue hemorrhagic fever [serial online]. Pubmed. 1989 [cited 2012 Nov 23] ;20:1925. Available from: http://www.ncbi.nlm. nih.gov/pubmed/2772702. 
7. Harrison P. Platelet Function Analysis. Elsevier. 2005;19:111-123.

8. Santoso D, Alwi EH, Idjradinata PS. Validitas kadar laktat dalam mendeteksi kebocoran plasma pada infeksi virus dengue anak. Majalah Kedokteran Indonesia. 2011;61:58-62.

9. Goldsmith HL, Kaufer ES, Mclntosh FA. Effect of hematocrit on adenosine diphosphate-induced Aggregation of human platelets in tube flow. Pubmed. 1995;32:573-52. [cited 2012 Dec 12]. Available from: http://www.ncbi.nlm.nih. gov/pubmed/8541523.

10. Departemen Kesehatan. Tata Laksana DBD [homepage on the Internet]. 2010 [cited 2012 Dec 27]. Available from: http://depkes.go.id/downloads/Tata\%20La
ksana\%20DBD.pdf.

11. Halstead S. Arbovirus; Demam berdarah dengue dan sindrom syok dengue. In: Nelson WE, Behrman RE, Kliegman R, Arvin AM, editors. Nelson Ilmu Kesehatan Anak Vol 2 (Edisi 15). Jakarta: EGC, 2000; p.1134-5.

12. Hassan $\mathbf{R}$, Alatas $\mathbf{H}$, editors. Dengue. In: Ilmu Kesehatan Anak (Edisi 11). Jakarta: Bagian Ilmu Kesehatan Anak FKUI, 2007; p.607-21.

13. Noisakran S, Perng GC. Alternate hypothesis on the pathogenesis of dengue hemorrhagic fever (DHF)/Dengue shock syndrome (DSS) in dengue virus infection. Experimental Biology and Medicine. 2008;233:401-8. 